\title{
Independent and Combined Effect of Some Soil Tillage Systems on Nitrogen and Carbon Concentration in Soil Structural Units of Haplic Chernozems
}

\author{
Margarita Nankova ${ }^{1}$ and Peter Yankov ${ }^{2}$ \\ 1. Dobrudzha Agricultural Institute, General Toshevo 9520, Bulgaria \\ 2. Technical University of Varna, Varna 9010, Bulgaria
}

\begin{abstract}
This paper aimed at studying the effect of different types of soil tillage systems on the change of total carbon (C) and nitrogen $(\mathrm{N})$ in the soil structural units of different size after dry structural analysis of soil. The research was carried out in a 6-field rotation system (grain maize-wheat-sunflower-wheat-bean-wheat) at the end of the 2nd rotation. Six out of 24 soil tillage systems were selected; they were applied independently and in combination in the crop rotation. After that, they were compared to the system with constant deep plowing. So a total of seven soil tillage systems were investigated. The selected systems for main soil tillage were the following: plowing (control variant), disking, cutting, nil tillage (direct sowing), plowing-disking, plowing-nil tillage, disking-nil tillage. Three depths of 0-10, 10-20 and 20-30 cm were studied, as well as soil structural units were of the following sizes: > $10 \mathrm{~mm}$, 10-5, 5-3, 3-1, 1-0.25 mm and $<0.25 \mathrm{~mm}$. As a result of systematic implementation of different soil tillage systems, higher $\mathrm{N}$ and $\mathrm{C}$ concentrations were established by the layers according to constant plowing. Constant disking and its alternation with nil tillage increased the total $\mathrm{N}$ concentration with $15.6 \%$ and $11.1 \%$, respectively, in comparison with the constant plowing. The same was valid for $\mathrm{C}$ concentration in soil, but the highest increase was established in the variants with constant cutting and nil tillage. The exceeding was with $14.0 \%$ and $13.2 \%$, in comparison to constant plowing. The redistribution of $\mathrm{N}$ and $\mathrm{C}$ depending on the structural soil units was most expressed in the $0-10 \mathrm{~cm}$ and 10-20 cm layers. The highest amounts of $\mathrm{C}$ and $\mathrm{N}$ were found in the soil units with size less than $5 \mathrm{~mm}$, mainly in the $<0.25 \mathrm{~mm}$ fraction. At depth of $20-30 \mathrm{~cm}$, the role of the size of soil structural units for $\mathrm{C}$ and $\mathrm{N}$ redistribution decreased strongly. The values of $\mathrm{C} / \mathrm{N}$ ratio were moderate only under the use of constant disking. This index was low under all other soil tillage systems. The correlation of total $\mathrm{N}$ with $\mathrm{C}$ in soil was high, positive and significant depending on the size of structural soil units and the tillage systems, as average for the investigated factors in this experiment. The minimal tillage and the tillage without turning of soil, used independently and in combination, had the highest contribution to preserving the organic matter in the haplic Chernozems of Dobrudzha region.
\end{abstract}

Key words: Soil tillage systems, soil C, total soil N, soil structural units.

\section{Introduction}

Tillage and crop rotation influence crop productivity in two ways. In the short-term, they cause changes in soil water and $\mathrm{N}$ dynamics [1]; in the long-term, they affect the soil organic matter dynamics and other soil fertility properties [2-4]. Crop response to different tillage systems and crop rotations are highly influenced by soil conditions, including soil drainage class, soil texture, soil organic matter, water

\footnotetext{
Corresponding author: Margarita Nankova, professor,
} research field: agro-chemistry. holding capacity and weather variables, such as temperature, precipitation amount and distribution, and frost-free days [5, 6].

Organic matter in soil, its content, composition and morphology are important diagnostic features, which give valuable information for soils and soil processes. Therefore, the status of the organic matter serves as a basis for investigations on soil fertility preservation and sustainable land management [7-9].

Tillage systems and fertilizer management influence the agrochemical and agrophysical soil characteristics. Their interactive effects remain to be 
determined for various soil and climatic conditions. Poirier et al. [10] evaluated the long-term effects of tillage (no-tillage and moldboard plowing), and $\mathrm{N}$ and P fertilization on soil organic matter (SOC) stocks and concentration in profiles of a clay loam soil (clayey, mixed, mesic, typic humaquept). The authors established the highest SOC stocks in $0-20 \mathrm{~cm}$ soil layer in the no-tillage treatment with the highest $\mathrm{N}$ rates, reflecting a greater residue accumulation at the soil surface. When accounting for the whole soil profile, the variations in surface SOC due to tillage and fertilizer interactions were masked by tillage-induced differences in the $20-30 \mathrm{~cm}$ soil layer.

Gregorich et al. [11] used a sequential density and particle-size fractionation to evaluate the total quantity and distribution of organic $\mathrm{C}$ and $\mathrm{N}$ in the profile of soils under mouldboard plowing and no-till. They attributed differences observed in whole soil C and $\mathrm{N}$ due to tillage mostly to differences in mineral-associated organic matter, particularly in soils with heavier textures. The other size and density fractions could, together, account for as much as $25 \%$ of the difference. It was established that the mechanical soil fractions of various size differed in their humus and $\mathrm{N}$ content. The authors pointed out that these were concentrated mainly in the uliginous and small dusty fractions.

The study on the regularities of humus and $\mathrm{N}$ distribution in granulometric fractions is important for understanding the process of organic matter accumulation in a certain soil type. In scientific literature, there are data indicating that in most cases the organic matter content considerably decreases in the larger soil units. The fine dispersion units (silt and fine dust) concentrate significantly more humus in the Chernozems than in the other soil types [12]. In the Chernozem zone of Khazakstan, Kiryushin and Lebedeva have also established the maximal content of humus in the small dusty fractions, and the humic content falls down with the increase of the fraction size [13].
The specific objectives of this study were to: (1) obtain information on the distribution of soil $\mathrm{C}$ and total $\mathrm{N}$ according to the structural soil units under different soil tillage systems; (2) identify appropriate tillage systems for preserving the organic matter and total $\mathrm{N}$; (3) evaluate the changes in correlation relationships between $\mathrm{C}, \mathrm{N}$ and the $\mathrm{C} / \mathrm{N}$ ratio according to the soil tillage systems and the structural soil units.

\section{Materials and Methods}

\subsection{Experiment Locations}

Dobrudzha Agricultural Institute (DAI), General Toshevo is situated in the North-Eastern part of Bulgaria in the zone of black earth (Fig. 1). The agricultural researches in the Dobrudzha region began in 1941 with the establishment of the Agricultural Research Station. In 1951, Dobrudzha Agricultural Institute was re-established at its current location, and continued the investigations on the problems of the agronomy practices applicable in the region.

\subsection{Experiment Layout and Design}

The investigation was carried out in a stationery field trial in 6-field crop rotation under the following rotation scheme: grain maize-wheat-sunflower-wheat -bean-wheat. The trial was initiated in 1987 on slightly leached Chernozem soil—haplic Chernozems [14]. It was designed by the non-standard method in eight

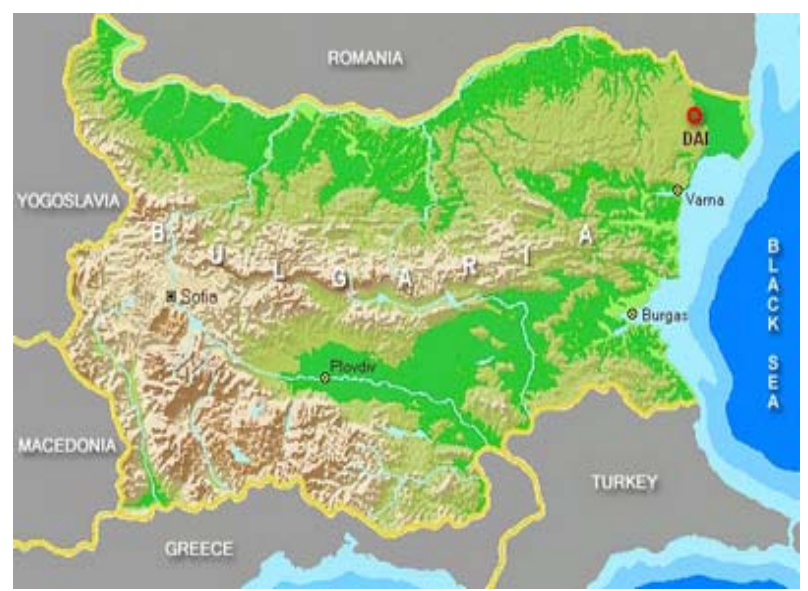

Fig. 1 Location of Dobrudzha Agriculture Institute (43 ${ }^{\circ}$ $40^{\prime}$ Northern latitude and $28^{\circ} 10^{\prime}$ Eastern longitude). 
replications. The size of the plot was $72 \mathrm{~m}^{2}$.

The mineral fertilization with triple superphosphate $\mathrm{Ca}\left(\mathrm{H}_{2} \mathrm{PO}_{4}\right)_{2}$ with $46 \% \mathrm{P}_{2} \mathrm{O}_{5}$ and $\mathrm{KCl}$ used in the entire crop rotation system involved the same $\mathrm{P}$ and $\mathrm{K}$ background, i.e., $120 \mathrm{~kg} \mathrm{P}_{2} \mathrm{O}_{5} / \mathrm{ha}$ and $80 \mathrm{~kg} \mathrm{~K} 2 \mathrm{O} / \mathrm{ha}$. The norm of $\mathrm{N}$ fertilization depended on the type of the previous and the current crop. The direct $\mathrm{N}$ fertilization for grain maize as the current crop was $160 \mathrm{~kg} \mathrm{~N} / \mathrm{ha}$, for sunflower $60 \mathrm{~kg} \mathrm{~N} / \mathrm{ha}$ and for bean $40 \mathrm{~kg} \mathrm{~N} / \mathrm{ha}$. Depending on its position in the crop rotation, wheat was fertilized with the following amounts of $\mathrm{N}$ : after grain maize $140 \mathrm{~kg} \mathrm{~N} / \mathrm{ha}$, after sunflower $160 \mathrm{~kg}$ N/ha and after bean $120 \mathrm{~kg}$ N/ha. The $\mathrm{N}$ fertilizer used was ammonium nitrate. In the spring crops, the $\mathrm{N}$ fertilizers were applied as single treatment prior to sowing; in wheat, one-thirds of the $\mathrm{N}$ norm was applied prior to planting, and the rest of the amount was at tillering stage in spring.

Out of the 24 soil tillage systems, seven were selected for the purpose of this investigation; they were based on different soil tillage tools and types of cultivation (Table 1).

At the end of two complete rotations since the initiation of the trial, soil samples were taken from layers $0-10,10-20$ and 20-30 cm. The soil structure was determined through dry and wet sifting of soil. The analysis of soil units was done by the method of Savinov in the modification of the method of Revut [15].

The percent ratio of the structural soil units of different size (> $10 \mathrm{~mm}, 10-5,5-3,3-1,1-0.25 \mathrm{~mm}$ and $<0.25 \mathrm{~mm}$ ) was determined as the method in Ref. [16].
C content was determined by the method of Tyurin and total $\mathrm{N}$ was by the method of Kjeldahl $[8,17]$.

Analysis of variance was performed for all response variables for a split-plot treatment arrangement using the procedures of the ANOVA to evaluate the significance of all measurement parameters. Treatment means were separated by the least significance difference (LSD) test. All significant differences are reported at the 5\% level.

\section{Results and Discussion}

Based on the ANOVA results, both the independent and the combined interaction of factors were highly significant, as average for the trial (Table 2). Each of the investigated agrochemical indices was influenced in various degrees by the type of soil tillage system, the depth of the soil layer and the size of the soil units. The C content in soil was affected in approximately similar degree by the depth of the soil layer and the type of the soil tillage system. The combined interaction between these two factors was better expressed in comparison to the other combinations between the factors (Fig. 2).

This tendency was confirmed for total $\mathrm{N}$ content in soil as well. The dominant role of the depth of the soil layer was even better expressed in comparison to its effect on the $C$ values.

The strength of the effect of the soil structural units factor, although significant, was considerably weaker (4\%-6\%) in comparison to the effects of the independent action of the depth and tillage system factors. The presence of this factor in the combined

Table 1 Tested systems of main soil tillage.

\begin{tabular}{lll}
\hline \multirow{2}{*}{ Soil tillage system } & \multicolumn{2}{c}{ Depth of tillage $(\mathrm{cm})$} \\
\cline { 2 - 3 } & Spring crops & Wheat \\
\hline 1. Plowing (check/control) & $24-26$ & $14-16$ \\
2. Disking & $10-12$ & $10-12$ \\
3. Cutting & $24-26$ & $8-10$ \\
4. Nil tillage (direct sowing) & Direct planting & Direct planting \\
5. Plowing-disking & $24-26$ & $10-12$ \\
6. Plowing-nil tillage & $24-26$ & Direct planting \\
7. Disking-nil tillage & $10-12$ & Direct planting \\
\hline
\end{tabular}


Table 2 Analysis on the variances of the trial's factors.

\begin{tabular}{lllllll}
\hline Source & Dependent variable & Type III sum of squares & df & Mean square & F & Significance \\
\hline \multirow{3}{*}{ Depth (1) } & Total C (\%) & 1.174 & 2 & 0.587 & 380.212 & 0.000 \\
& Total N (mg) & $21,938.315$ & 2 & $10,969.157$ & 256.709 & 0.000 \\
& C/N & 8.912 & 2 & 4.456 & 17.654 & 0.000 \\
\hline \multirow{5}{*}{ Soil units size (2) } & Total C (\%) & 0.178 & 5 & 0.036 & 23.066 & 0.000 \\
& Total N (mg) & $3,520.228$ & 5 & 704.046 & 16.477 & 0.000 \\
& C/N & 4.841 & 5 & 0.968 & 3.836 & 0.003 \\
\hline \multirow{3}{*}{ Tillage systems (3) } & Total C (\%) & 1.135 & 6 & 0.189 & 122.583 & 0.000 \\
& Total N (mg) & $15,051.600$ & 6 & $2,508.600$ & 58.708 & 0.000 \\
& C/N & 79.494 & 6 & 13.249 & 52.491 & 0.000 \\
\hline \multirow{4}{*}{$1 \times 2$} & Total C (\%) & 0.178 & 10 & 0.018 & 11.517 & 0.000 \\
& Total N (mg) & $1,209.318$ & 10 & 120.932 & 2.830 & 0.003 \\
& C/N & 10.221 & 10 & 1.022 & 4.050 & 0.000 \\
\hline \multirow{3}{*}{$1 \times 3$} & Total C (\%) & 1.098 & 12 & 0.092 & 59.284 & 0.000 \\
& Total N (mg) & $14,527.734$ & 12 & $1,210.644$ & 28.333 & 0.000 \\
& C/N & 16.326 & 12 & 1.361 & 5.390 & 0.000 \\
\hline \multirow{3}{*}{$2 \times 3$} & Total C (\%) & 0.275 & 30 & 0.009 & 5.929 & 0.000 \\
& Total N (mg) & $3,874.307$ & 30 & 129.144 & 3.022 & 0.000 \\
& C/N & 17.908 & 30 & 0.597 & 2.365 & 0.000 \\
\hline \multirow{2}{*}{$1 \times 2 \times 3$} & Total C (\%) & 0.326 & 60 & 0.005 & 3.517 & 0.000 \\
& Total N (mg) & $6,716.125$ & 60 & 111.935 & 2.620 & 0.000 \\
& C/N & 46.106 & 60 & 0.768 & 3.044 & 0.000 \\
\hline
\end{tabular}

The ratio of $\mathrm{C} / \mathrm{N}$ is between $\mathrm{C} \%$ and $\mathrm{N} \%$ after recalculation, according to Orlov and Grishina [18].

interactions with the other factors reduced the strength of their effect.

It was found that the $\mathrm{C} / \mathrm{N}$ ratio was mostly affected by the type of the soil tillage system (43.25\%), followed by the full combined interaction between the two factors.

The detailed analysis on the obtained results revealed differentiation by significance level of the agrochemical parameters depending on the size of soil units and the type of soil tillage system (Table 3). The depth of the soil layer in all tested systems had significant effect on the content of $\mathrm{C}$ and $\mathrm{N}$ in soil. The same was valid for the $\mathrm{C} / \mathrm{N}$ ratio under constant use of systems with partial or no turning of the soil layer (the 2nd, 3rd and 4th system) and under alternation of plowing and disking (the 6th system). The magnitude of the effect of long-term use of different types of tillage is driven by soil properties [19-22], the timing and frequency of tillage events [23, 24], climate [6, 25] and choice of crop [26-28].
The soil units of various sizes had significantly different content of $\mathrm{C}$ and $\mathrm{N}$ under the long-term independent use of constant main types of soil tillage. Among the alternated tilths, this was valid only for the annual plowing-direct sowing alternation (the 6th system).

The variations of $\mathrm{C} / \mathrm{N}$ ratio in the soil units of different sizes were significantly influenced under the 1st (plowing), 2nd (disking) and 4th (direct sowing) systems. The combined effect of the two factors had significant influence on the values of the agrochemical characters only under constant use of plowing in the crop rotation.

The differentiation in the values of total $\mathrm{C}$ and $\mathrm{N}$ and their ratio clearly showed the differences in their content formed in the respective soil layers depending on the soil tillage system in the crop rotation (Table 4). The annual plowing, especially of the surface $0-10 \mathrm{~cm}$ layer, led to the lowest content of $\mathrm{C}$ and $\mathrm{N}$ as distinct differentiation by layers, this tendency toward compared 


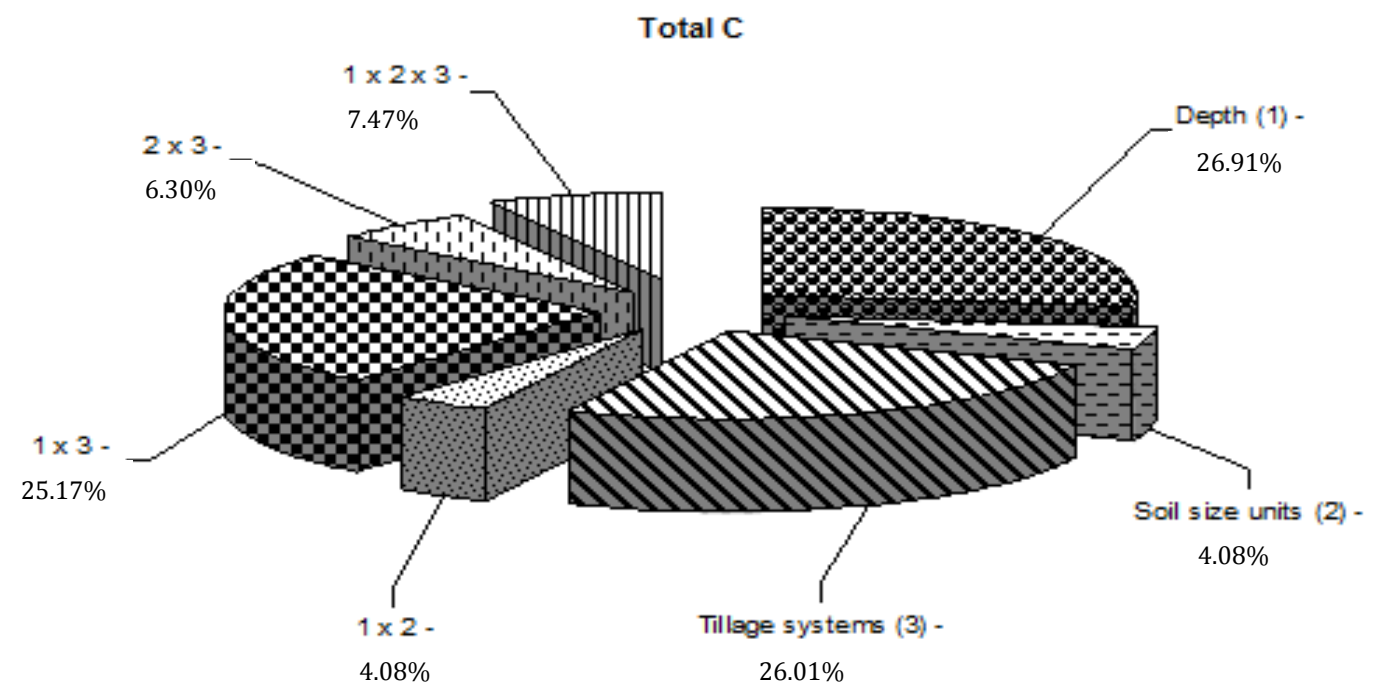

Total N
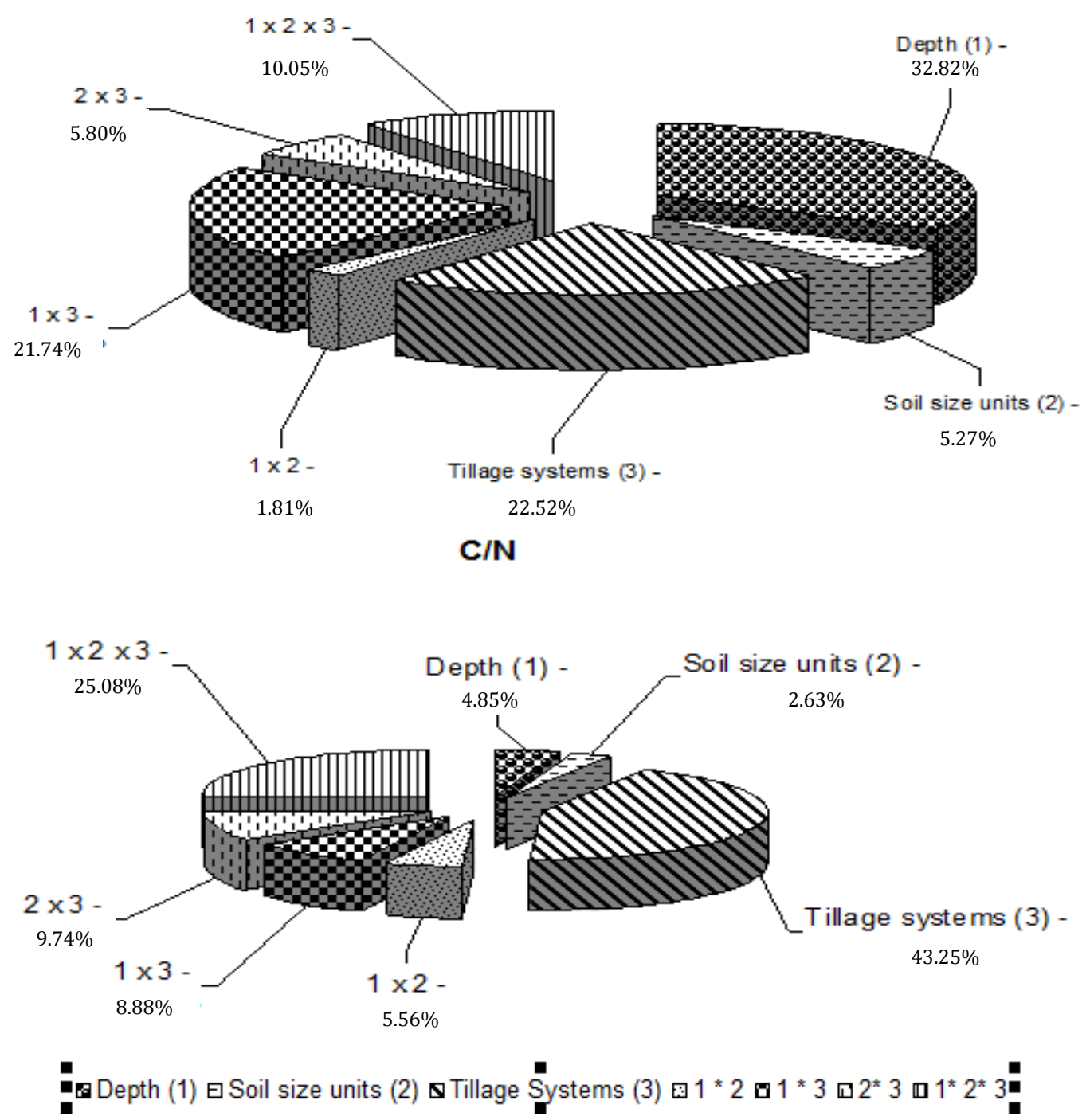

Fig. 2 Strength of factors effect (\%). 
Table 3 Analysis of the variances according to soil tillage systems.

\begin{tabular}{|c|c|c|c|c|c|c|c|c|c|}
\hline \multirow{2}{*}{ Source } & \multirow{2}{*}{ Dependent variable } & \multirow{2}{*}{ df } & \multicolumn{7}{|c|}{ Soil tillage systems } \\
\hline & & & 1 & 2 & 3 & 4 & 5 & 6 & 7 \\
\hline \multirow{3}{*}{ Soil size units (1) } & $\mathrm{C}$ & 5 & 0.001 & 0.003 & 0.000 & 0.000 & 0.004 & 0.000 & $0.018^{\mathrm{NS}}$ \\
\hline & $\bar{N}$ & 5 & 0.001 & 0.000 & 0.002 & 0.000 & $0.020^{\mathrm{NS}}$ & 0.000 & $0.196^{\mathrm{NS}}$ \\
\hline & $\mathrm{C} / \mathrm{N}$ & 5 & 0.013 & 0.003 & $0.080^{\mathrm{NS}}$ & 0.005 & $0.043^{\mathrm{NS}}$ & $0.037^{\mathrm{NS}}$ & $0.181^{\mathrm{NS}}$ \\
\hline \multirow{3}{*}{ Depth (2) } & $\mathrm{C}$ & 2 & 0.000 & 0.000 & 0.000 & 0.000 & 0.000 & 0.000 & 0.000 \\
\hline & $\mathrm{N}$ & 2 & 0.000 & 0.000 & 0.000 & 0.000 & 0.000 & 0.000 & 0.000 \\
\hline & $\mathrm{C} / \mathrm{N}$ & 2 & $0.062^{\mathrm{NS}}$ & 0.000 & 0.005 & 0.000 & $0.021^{\mathrm{NS}}$ & 0.000 & $0.116^{\mathrm{NS}}$ \\
\hline \multirow{3}{*}{$1 \times 2$} & $\mathrm{C}$ & 10 & 0.000 & $0.019^{\mathrm{NS}}$ & 0.000 & 0.011 & 0.002 & 0.005 & 0.009 \\
\hline & $\mathrm{N}$ & 10 & 0.000 & 0.001 & 0.007 & $0.044^{\mathrm{NS}}$ & 0.008 & 0.002 & $0.456^{\mathrm{NS}}$ \\
\hline & $\mathrm{C} / \mathrm{N}$ & 10 & 0.000 & 0.013 & 0.004 & $0.037^{\mathrm{NS}}$ & $0.017^{\mathrm{NS}}$ & $0.119^{\mathrm{NS}}$ & $0.086^{\mathrm{NS}}$ \\
\hline
\end{tabular}

NS: variations and effects are not significant.

Table $4 \mathrm{C}$ and $\mathrm{N}$ concentration and their ratio according to soil tillage system and soil depth.

\begin{tabular}{|c|c|c|c|c|}
\hline Soil tillage systems & Depth $(\mathrm{cm})$ & $\mathrm{C}(\%)$ & N (mg/100 g) & $\mathrm{C} / \mathrm{N}$ \\
\hline \multirow{3}{*}{ 1. Plowing (control) } & $0-10$ & $1.47^{\mathrm{a}}$ & $153.24^{\mathrm{a}}$ & $11.27^{\mathrm{a}}$ \\
\hline & $10-20$ & $1.56^{\mathrm{b}}$ & $156.94^{\mathrm{b}}$ & $11.68^{\mathrm{b}}$ \\
\hline & $20-30$ & $1.60^{\mathrm{c}}$ & $164.72^{\mathrm{C}}$ & $11.46^{\mathrm{ab}}$ \\
\hline \multirow{3}{*}{ 2. Disking } & $0-10$ & $1.84^{\mathrm{C}}$ & $197.38^{c}$ & $10.94^{\mathrm{b}}$ \\
\hline & $10-20$ & $1.65^{\mathrm{b}}$ & $186.69^{b}$ & $10.39^{\mathrm{a}}$ \\
\hline & $20-30$ & $1.60^{\mathrm{a}}$ & $164.71^{\mathrm{a}}$ & $11.37^{\mathrm{c}}$ \\
\hline \multirow{3}{*}{ 3. Cutting } & $0-10$ & $1.93^{\mathrm{b}}$ & $188.05^{c}$ & $12.00^{\mathrm{b}}$ \\
\hline & $10-20$ & $1.67^{\mathrm{a}}$ & $170.16^{\mathrm{b}}$ & $11.51^{\mathrm{a}}$ \\
\hline & $20-30$ & $1.67^{\mathrm{a}}$ & $159.09^{\mathrm{a}}$ & $12.32^{\mathrm{b}}$ \\
\hline \multirow{3}{*}{ 4. Nil tillage } & $0-10$ & $1.92^{\mathrm{C}}$ & $181.44^{\mathrm{C}}$ & $12.41^{\mathrm{a}}$ \\
\hline & $10-20$ & $1.71^{\mathrm{b}}$ & $156.55^{\mathrm{b}}$ & $12.80^{\mathrm{b}}$ \\
\hline & $20-30$ & $1.66^{\mathrm{a}}$ & $146.82^{\mathrm{a}}$ & $13.28^{\mathrm{c}}$ \\
\hline \multirow{3}{*}{ 5. Plowing-disking } & $0-10$ & $1.78^{\mathrm{C}}$ & $181.24^{\mathrm{b}}$ & $11.50^{\mathrm{a}}$ \\
\hline & $10-20$ & $1.64^{\mathrm{a}}$ & $162.19^{\mathrm{a}}$ & $11.86^{\mathrm{b}}$ \\
\hline & $20-30$ & $1.66^{\mathrm{b}}$ & $162.19^{\mathrm{a}}$ & $12.02^{\mathrm{b}}$ \\
\hline \multirow{3}{*}{ 6. Plowing-nil tillage } & $0-10$ & $1.66^{\mathrm{b}}$ & $176.38^{\mathrm{b}}$ & $11.02^{\mathrm{a}}$ \\
\hline & $10-20$ & $1.69^{c}$ & $167.24^{\mathrm{a}}$ & $11.81^{\mathrm{c}}$ \\
\hline & $20-30$ & $1.62^{\mathrm{a}}$ & $168.02^{\mathrm{a}}$ & $11.27^{\mathrm{b}}$ \\
\hline \multirow{3}{*}{ 7. Disking-nil tillage } & $0-10$ & $1.88^{\mathrm{b}}$ & $202.44^{\mathrm{b}}$ & $10.95^{\mathrm{a}}$ \\
\hline & $10-20$ & $1.65^{\mathrm{a}}$ & $163.94^{\mathrm{a}}$ & $11.77^{\mathrm{a}}$ \\
\hline & $20-30$ & $1.58^{\mathrm{a}}$ & $161.41^{\mathrm{a}}$ & $11.58^{\mathrm{a}}$ \\
\hline
\end{tabular}

${ }^{\mathrm{a}-\mathrm{c}}$ Values with the same letter are not significantly different at $P \leq 0.05$. According to Orlov and Grishina [18], the ration of C/N was between C\% and N\% after recalculating the $\mathrm{N}$ mg to $\mathrm{N} \%$.

to the other systems. Regardless of the decrease of total $\mathrm{C}$ and $\mathrm{N}$ was affected by the layer below the 10-20 cm layer.

Under the rest of the independently used soil tillage systems, a tendency opposite to that of plowing was observed. The highest concentration of total $\mathrm{C}$ and $\mathrm{N}$ was found in the surface layer and their content decreased down the soil profile. The amplitude of this differentiation in the values of the indices between layers $0-10 \mathrm{~cm}$ and $20-30 \mathrm{~cm}$ was greatest under the systems with constant use of cutting and nil tillage.

The 0-10 cm layer was definitely with the highest content of $\mathrm{N}$ and $\mathrm{C}$ in soil, averaged for the tested systems (Fig. 3). With regard to $\mathrm{C}$ concentration, it was highest (1.91\%) under the systems without turning of the soil layer (cutting and nil); the exceeding of 


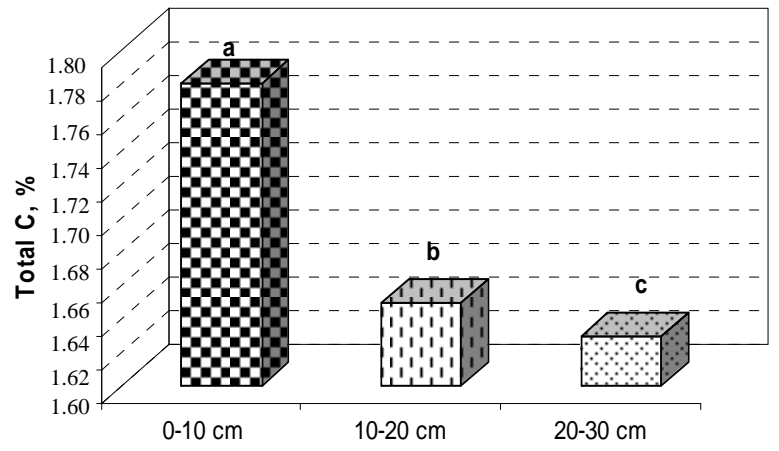

(a) Total C (\%)

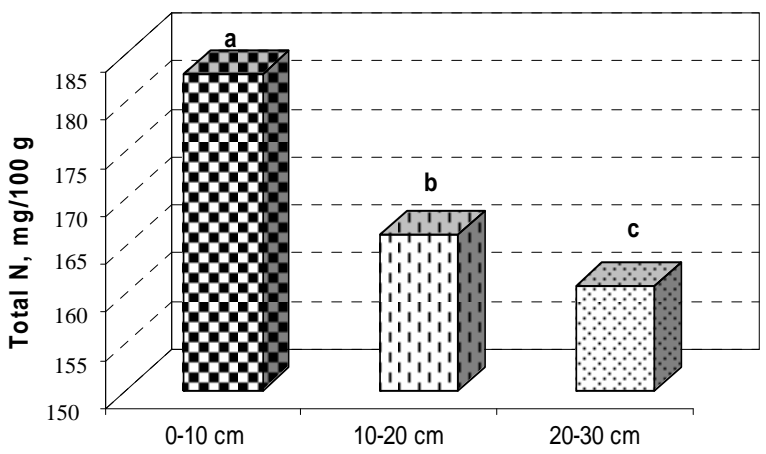

(b) Total N (mg/100 g)

Fig. 3 Total $\mathrm{C}$ and $\mathrm{N}$ concentration according to soil depth.

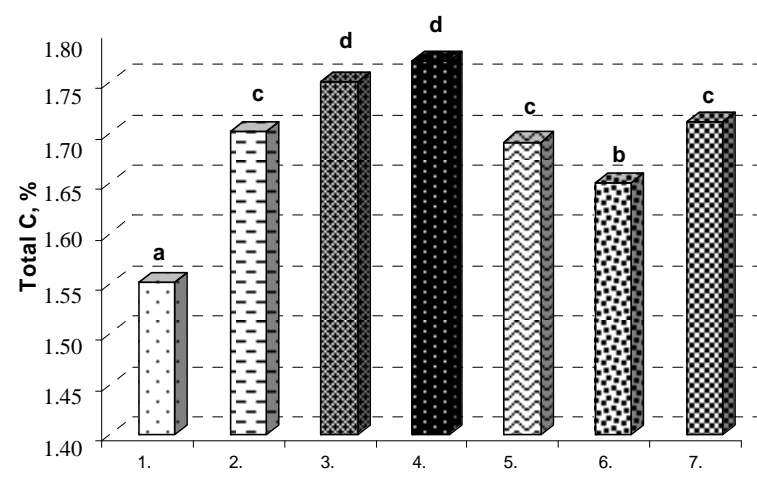

(a) Total C (\%)

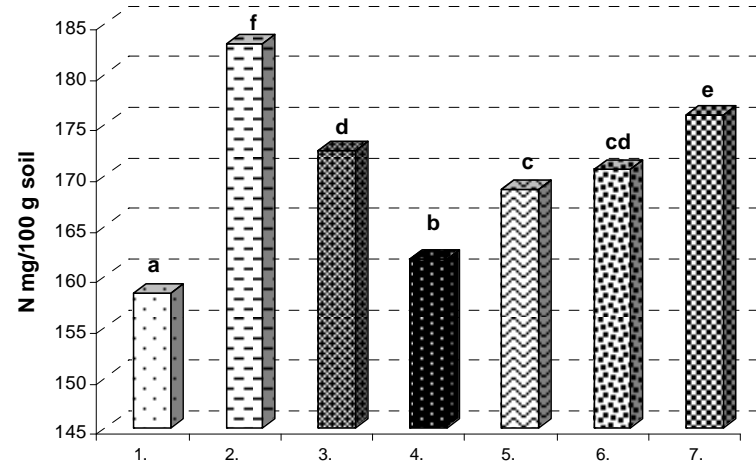

(b) Total N (mg/100 g)

Fig. 4 Total $\mathrm{C}$ and $\mathrm{N}$ concentration according to type of soil tillage system (Waller-Dunkan test).

* Values with the same letter are not significantly different at $P \leq 0.05$.

this value under plowing was $30.2 \%$. The rest of the systems for soil tillage also exceeded constant plowing by content of $\mathrm{C}$ in this layer.

This tendency remained valid also for the $10-20 \mathrm{~cm}$ layer regardless of the gradual decrease of $\mathrm{C}$ concentration. Only in the 20-30 cm layer, the differences between the separate soil tillage systems decreased considerably. The most significant enrichment of the surface layer $(0-10 \mathrm{~cm})$ with $\mathrm{N}$ was registered under the alternation of disking and nil tillage with a mean value of $202.44 \mathrm{mg}$ N/100 g soil. This investigation confirms previous results in Ref. [29]. In the following depths down the soil profile, the variants with combined tillage were equal. Under constant disking, the root-deep horizon had total $\mathrm{N}$ content in soil with $15.56 \%$ higher than under plowing. At the alternation of disking and nil tillage, this increasing was with $11.14 \%$ higher than under plowing. Long-term tillage studies (in Prince Edward Island, Québec and at two sites in Ontario) on soils of different textures showed that plowing also had a substantial and consistent positive effect on the quantity of $\mathrm{C}$ (and in some cases of $\mathrm{N}$ ) protected within aggregates, particularly at or near the bottom of the plow layer and sometimes in surface soil layers [11].

Among all tested tillage systems, the variant with independent use of plowing had the lowest $\mathrm{C}$ content, averaged for the $0-30 \mathrm{~cm}$ layer (Fig. 4). Its content, however, showed a tendency towards decrease with the increased soil depth along the profile. Its content decreased along the depth profile under all other tillage systems.

The highest values were registered at independent 
application of cutter tillage and direct sowing. The highest differentiation in the $\mathrm{C}$ content was determined under constant use of cutting and nil tillage in crop rotation. Incorporation of residue into the soil surface in shallower rototiller tillage (ST-10 cm depth) increased soil $\mathrm{N}$ compared to mouldboard plow (MT-20-25 cm depth) by increasing $\mathrm{N}$ mineralization from the residue [30].

The variable effect of the tested soil tillage systems on the values of the studied agrochemical characters of soil was found in the structural soil units of different sizes as well (Table 5). Apart from being the lowest, the $\mathrm{C}$ content in soil was also little affected by the size of soil units under constant plowing in crop rotation. The $\mathrm{C}$ and $\mathrm{N}$ distribution according to the size of soil units is related to the primary accumulation of products from the organic matter humification depending on the type of soil tillage system and the horizon depth.

Under the systems with alternation of the tillage types, especially those involving plowing, the differentiation in the $C$ values between the soil units of different size decreased (Fig. 5). The larger soil units had lower $\mathrm{C}$ concentration in comparison to the soil units valuable from an agronomic point of view, especially under constant use of tillage systems without turning of the soil layer (cutting and nil tillage).

Total $\mathrm{N}$ in soil was concentrated mostly in the valuable soil units and in the silty fraction. This tendency was the strongest in 0-10 cm layer under the systems with constant disking and nil tillage, and in the systems with their alternation. The tendency toward lower total $\mathrm{N}$ content in the larger soil units (> $10 \mathrm{~mm}$ and $10-5 \mathrm{~mm}$ ) was present under almost all soil tillage systems, including the $20-30 \mathrm{~cm}$ layer. This

Table $5 \mathrm{C}$ and $\mathbf{N}$ concentration and their ratio according to the size of structural soil units under different soil tillage systems averaged for the $0-30 \mathrm{~cm}$ depth (Waller-Duncan $N=6$ ).

\begin{tabular}{|c|c|c|c|c|c|c|c|}
\hline \multirow{2}{*}{$\begin{array}{l}\text { Soil size units } \\
(\mathrm{mm})\end{array}$} & \multicolumn{7}{|c|}{ Soil tillage systems } \\
\hline & $\begin{array}{l}\text { 1. Plowing } \\
\text { (control) }\end{array}$ & 2. Disking & 3. Cutting & 4. Nil tillage & 5. Plowing-disking & $\begin{array}{l}\text { 6. Plowing-nil } \\
\text { tillage }\end{array}$ & $\begin{array}{l}\text { 7. Disking-nil } \\
\text { tillage }\end{array}$ \\
\hline \multicolumn{8}{|l|}{ Total C (\%) } \\
\hline$>10$ & $1.51^{\mathrm{a}}$ & $1.67^{\mathrm{a}}$ & $1.71^{\mathrm{ab}}$ & $1.72^{\mathrm{a}}$ & $1.70^{\mathrm{bc}}$ & $1.62^{\mathrm{a}}$ & $1.71^{\mathrm{b}}$ \\
\hline $10-5$ & $1.58^{\mathrm{b}}$ & $1.69^{\mathrm{a}}$ & $1.69^{\mathrm{a}}$ & $1.73^{\mathrm{a}}$ & $1.68^{\mathrm{ab}}$ & $1.62^{\mathrm{a}}$ & $1.69^{\mathrm{ab}}$ \\
\hline $5-3$ & $1.58^{\mathrm{b}}$ & $1.68^{\mathrm{a}}$ & $1.72^{\mathrm{b}}$ & $1.73^{\mathrm{a}}$ & $1.67^{\mathrm{a}}$ & $1.66^{\mathrm{b}}$ & $1.58^{\mathrm{a}}$ \\
\hline $3-1$ & $1.57^{\mathrm{b}}$ & $1.74^{\mathrm{c}}$ & $1.78^{\mathrm{c}}$ & $1.76^{\mathrm{b}}$ & $1.73^{\mathrm{c}}$ & $1.71^{\mathrm{C}}$ & $1.73^{\mathrm{b}}$ \\
\hline $1-0.25$ & $1.55^{\mathrm{b}}$ & $1.72^{\mathrm{bc}}$ & $1.79^{\mathrm{c}}$ & $1.79^{\mathrm{c}}$ & $1.70^{\mathrm{ab}}$ & $1.67^{\mathrm{b}}$ & $1.76^{\mathrm{b}}$ \\
\hline$<0.25$ & $1.51^{\mathrm{a}}$ & $1.70^{\mathrm{ab}}$ & $1.83^{\mathrm{d}}$ & $1.88^{\mathrm{d}}$ & $1.69^{\mathrm{ab}}$ & $1.65^{\mathrm{b}}$ & $1.76^{\mathrm{b}}$ \\
\hline \multicolumn{8}{|c|}{ Total N (mg/100 g soil) } \\
\hline$>10$ & $154.02^{\mathrm{a}}$ & $174.24^{\mathrm{a}}$ & $165.69^{\mathrm{a}}$ & $156.35^{\mathrm{a}}$ & $166.85^{\mathrm{ab}}$ & $169.58^{\mathrm{b}}$ & $172.69^{\mathrm{a}}$ \\
\hline $10-5$ & $156.74^{\mathrm{a}}$ & $176.19^{\mathrm{a}}$ & $162.96^{\mathrm{a}}$ & $157.13^{\mathrm{a}}$ & $165.30^{\mathrm{a}}$ & $161.41^{\mathrm{a}}$ & $170.35^{\mathrm{a}}$ \\
\hline $5-3$ & $155.96^{\mathrm{a}}$ & $178.91^{\mathrm{a}}$ & $175.41^{\mathrm{bc}}$ & $159.46^{\mathrm{ab}}$ & $173.08^{\mathrm{bc}}$ & $170.74^{\mathrm{bc}}$ & $181.25^{\mathrm{a}}$ \\
\hline $3-1$ & $164.13^{\mathrm{b}}$ & $190.19^{\mathrm{bc}}$ & $176.19^{\mathrm{bc}}$ & $162.19^{b}$ & $175.02^{c}$ & $176.58^{d}$ & $167.63^{\mathrm{a}}$ \\
\hline $1-0.25$ & $163.74^{\mathrm{b}}$ & $185.52^{\mathrm{b}}$ & $170.77^{\mathrm{ab}}$ & $167.63^{c}$ & $164.91^{\mathrm{a}}$ & $174.63^{\mathrm{cd}}$ & $180.85^{a}$ \\
\hline$<0.25$ & $155.18^{\mathrm{a}}$ & $192.52^{c}$ & $183.57^{c}$ & $166.85^{c}$ & $166.08^{\mathrm{ab}}$ & $170.36^{\mathrm{bc}}$ & $182.80^{\mathrm{a}}$ \\
\hline \multicolumn{8}{|l|}{$\mathrm{C} / \mathrm{N}$} \\
\hline$>10$ & $11.51^{\mathrm{abc}}$ & $11.22^{\mathrm{C}}$ & $12.08^{\mathrm{ab}}$ & $12.92^{\mathrm{bc}}$ & $12.00^{\mathrm{b}}$ & $11.17^{\mathrm{a}}$ & $11.60^{\mathrm{ab}}$ \\
\hline $10-5$ & $11.79^{\mathrm{bc}}$ & $11.19^{c}$ & $12.19^{\mathrm{b}}$ & $12.94^{\mathrm{bc}}$ & $11.89^{\mathrm{b}}$ & $11.73^{\mathrm{b}}$ & $11.59^{\mathrm{ab}}$ \\
\hline $5-3$ & $11.89^{c}$ & $10.97^{\mathrm{bc}}$ & $11.45^{\mathrm{a}}$ & $12.68^{\mathrm{ab}}$ & $11.32^{\mathrm{a}}$ & $11.39^{\mathrm{ab}}$ & $10.54^{\mathrm{a}}$ \\
\hline $3-1$ & $11.20^{\mathrm{a}}$ & $10.73^{\mathrm{ab}}$ & $11.96^{\mathrm{ab}}$ & $12.70^{\mathrm{ab}}$ & $11.56^{\mathrm{ab}}$ & $11.36^{\mathrm{a}}$ & $12.09^{\mathrm{b}}$ \\
\hline $1-0.25$ & $11.07^{\mathrm{a}}$ & $10.93^{\mathrm{bc}}$ & $12.32^{\mathrm{b}}$ & $12.51^{\mathrm{a}}$ & $12.08^{\mathrm{b}}$ & $11.20^{\mathrm{a}}$ & $11.46^{\mathrm{ab}}$ \\
\hline$<0.25$ & $11.37^{\mathrm{ab}}$ & $10.36^{\mathrm{a}}$ & $11.67^{\mathrm{ab}}$ & $13.21^{\mathrm{c}}$ & $11.91^{\mathrm{b}}$ & $11.36^{\mathrm{a}}$ & $11.34^{\mathrm{ab}}$ \\
\hline
\end{tabular}

${ }^{\mathrm{a}-\mathrm{c}}$ Values with the same letter are not significantly different at $P \leq 0.05$. The $\mathrm{C} / \mathrm{N}$ is between $\mathrm{C} \%$ and N\% after recalculation, according to Orlov and Grishina [18]. 


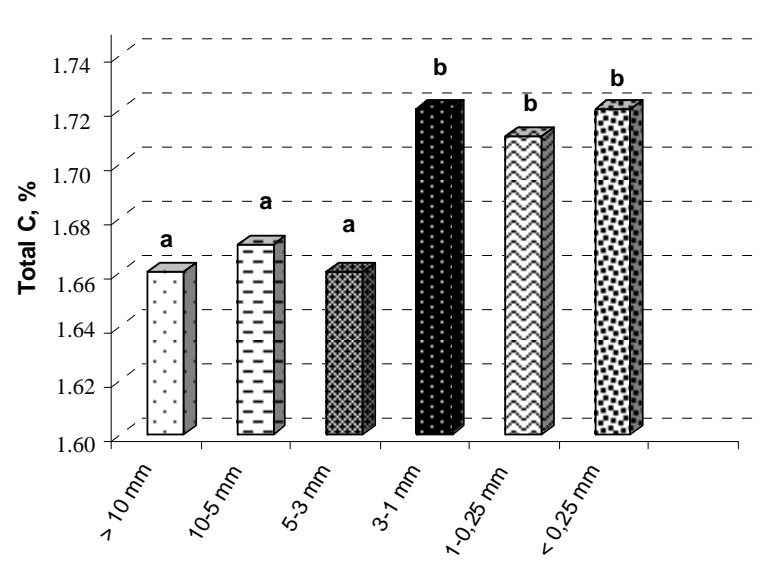

(a) Total C (\%)

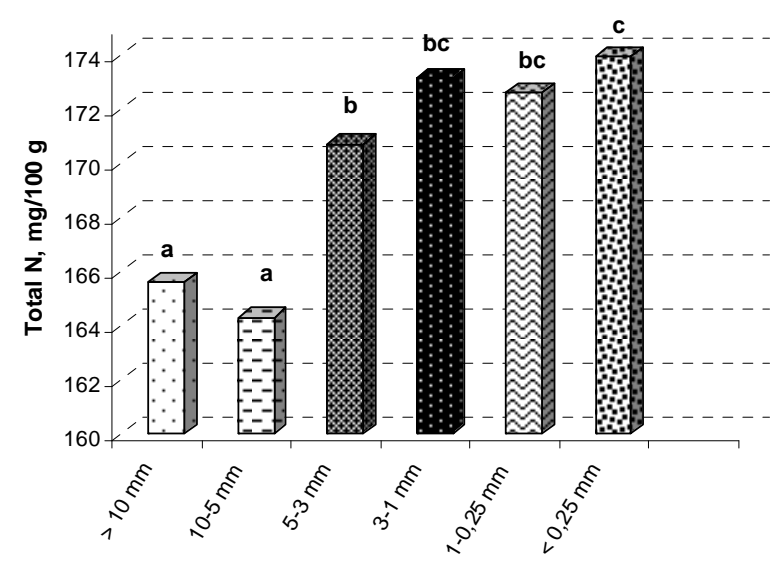

(b) Total N (mg/100 g)

Fig. 5 Total $\mathrm{C}$ and $\mathrm{N}$ concentration according to the size of structural soil units (Waller-Duncan $N=14$ ).

* Values with the same letter are not significantly different at $P \leq 0.05$.

layer remained the poorest in total $\mathrm{N}$ under constant cutting, followed by constant nil tillage. By their mean total $\mathrm{N}$ content at depth $20-30 \mathrm{~cm}$, the rest of the systems differed little between themselves.

A differentiation was established in the content of total $\mathrm{N}$ according to the size of soil units. The higher amounts of $\mathrm{N}$ were concentrated in the units smaller than $5 \mathrm{~mm}$. This tendency was most clear in the variant with alternation of disking and nil tillage, and at independent application of disking, nil tillage and cutter tillage. The size of structural soil units had the strongest effect on C content in the 0-10 cm layer. With the exception of plowing, all other soil tillage systems considerably enriched the smallest soil size units $<0.25 \mathrm{~mm}$ ) with total C.

Averaged for all sizes of structural soil units in the 0-30 cm horizon, the lowest total $\mathrm{N}$ content in soil was established in the variant with independent use of plowing.

Orlov and Grishina [18] consider the ratio between the agrochemical indices $\mathrm{C}$ and $\mathrm{N}$ as one of the qualitative characteristics of soils. It gives idea about the degree of humus enrichment with $\mathrm{N}$. The calculated values of the $\mathrm{C} / \mathrm{N}$ ratio according to the factors investigated in this experiment were moderate, between 8 and 11 under constant disking. Under all other soil tillage systems, the degree of humus enrichment with $\mathrm{N}$ was low. This was valid both for the soil units of different sizes and for the three analyzed soil layers.

The correlations between the investigated agronomy characters of soil showed that only under long-term annual use of plowing in the crop rotation, the correlation between $\mathrm{C}$ and $\mathrm{N}$ in the upper part of the root-deep layer (0-30 cm) was not significant (Fig. 6).

In all other soil tillage systems, this positive correlation was very high, reaching its maximum under constant direct sowing (+ 0.931**). The alternation of plowing with direct sowing and disking contributed for a significantly higher positive correlation between $\mathrm{C}$ and $\mathrm{N}$ in soil. Therefore, the correlations between total $\mathrm{N}$ in soil and the $\mathrm{C} / \mathrm{N}$ ratio were negative, significant and with values differentiated according to the system of soil tillage. The case with the correlation of $\mathrm{C}$ in soil with the $\mathrm{C} / \mathrm{N}$ ratio was different. Under constant plowing in crop rotation, the correlation was positive and significant, and under constant direct sowing, it was negative and significant. Under the rest of the soil tillage systems, the obtained values of this correlation were not significant.

In all investigated sizes of structural soil units, positive correlations between $\mathrm{C}$ and $\mathrm{N}$ concentrations were found (Table 6). The values of these relationships varied according to the size of the soil units. The correlation was higher in $5-10 \mathrm{~mm}$ and $<0.25 \mathrm{~mm}$ 


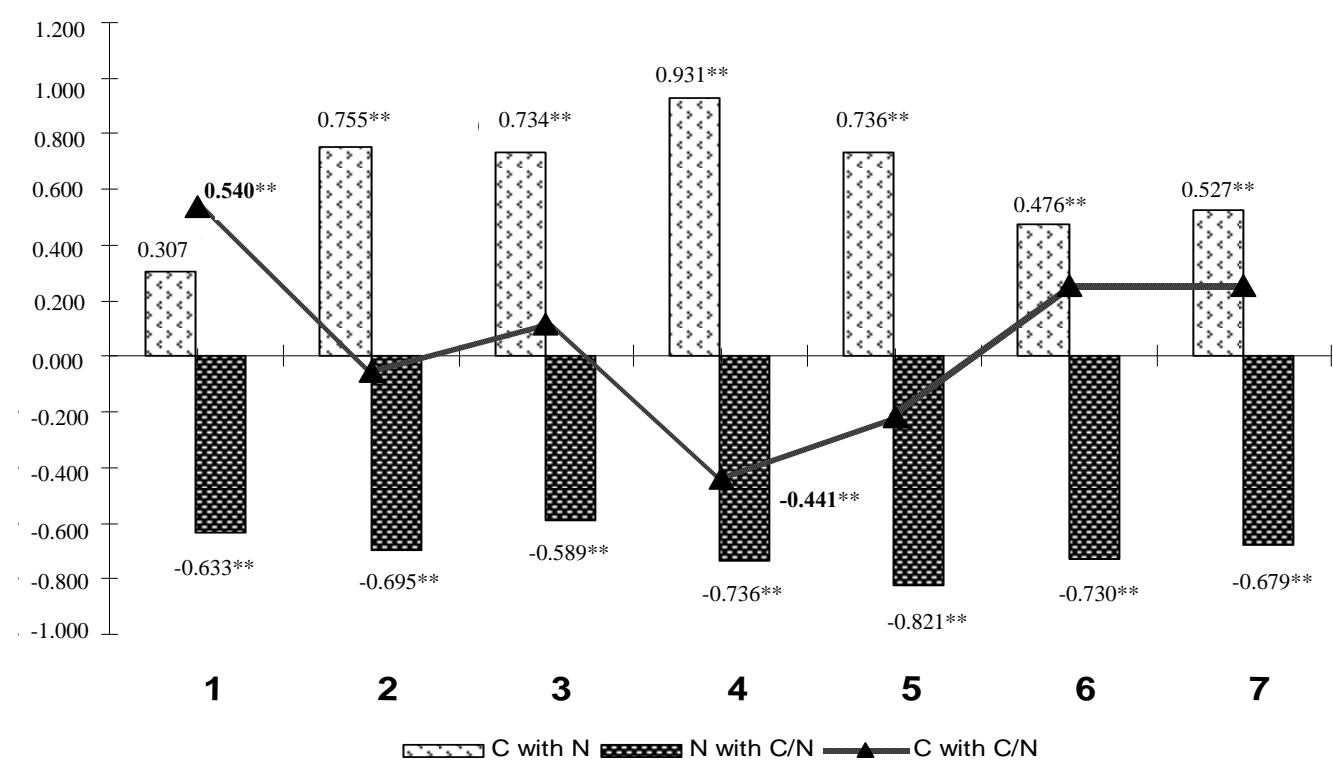

Fig. 6 Correlations between agrochemical characteristics of soil according to soil tillage systems (Pearson correlation).

Table 6 Correlations between agrochemical characteristics of soil according to the size of soil structural units (Pearson correlation).

\begin{tabular}{|c|c|c|c|}
\hline Indices & $\mathrm{C}$ & $\mathrm{N}$ & $\mathrm{C} / \mathrm{N}$ \\
\hline \multicolumn{4}{|c|}{$>10 \mathrm{~mm}$} \\
\hline $\mathrm{C}$ & 1 & $0.611^{* *}$ & 0.239 \\
\hline $\mathrm{N}$ & $0.611^{* *}$ & 1 & $-0.620^{* *}$ \\
\hline $\mathrm{C} / \mathrm{N}$ & 0.239 & $-0.620^{* *}$ & 1 \\
\hline \multicolumn{4}{|c|}{$10-5 \mathrm{~mm}$} \\
\hline $\mathrm{C}$ & 1 & $0.748^{* *}$ & -0.092 \\
\hline $\mathrm{N}$ & $0.748^{* *}$ & 1 & $-0.727^{* *}$ \\
\hline $\mathrm{C} / \mathrm{N}$ & -0.092 & $-0.727^{* *}$ & 1 \\
\hline \multicolumn{4}{|l|}{$5-3 \mathrm{~mm}$} \\
\hline $\mathrm{C}$ & 1 & 0.174 & $0.409^{* *}$ \\
\hline $\mathrm{N}$ & 0.174 & 1 & $-0.817^{* *}$ \\
\hline $\mathrm{C} / \mathrm{N}$ & $0.409^{* *}$ & $-0.817^{* *}$ & 1 \\
\hline \multicolumn{4}{|l|}{ 3-1 mm } \\
\hline $\bar{C}$ & 1 & $0.673^{* *}$ & 0.082 \\
\hline $\mathrm{N}$ & $0.673^{* *}$ & 1 & $-0.678^{* *}$ \\
\hline $\mathrm{C} / \mathrm{N}$ & 0.082 & $-0.678^{* *}$ & 1 \\
\hline \multicolumn{4}{|c|}{$1-0.25 \mathrm{~mm}$} \\
\hline $\bar{C}$ & 1 & $0.574^{* *}$ & $0.347^{*}$ \\
\hline $\mathrm{N}$ & $0.574^{* *}$ & 1 & $-0.566^{* *}$ \\
\hline $\mathrm{C} / \mathrm{N}$ & $0.347^{*}$ & $-0.566^{* *}$ & 1 \\
\hline \multicolumn{4}{|c|}{$<0.25 \mathrm{~mm}$} \\
\hline $\mathrm{C}$ & 1 & $0.702^{* *}$ & 0.284 \\
\hline $\mathrm{N}$ & $0.702^{* *}$ & 1 & $-0.478^{* *}$ \\
\hline $\mathrm{C} / \mathrm{N}$ & 0.284 & $-0.478^{* *}$ & 1 \\
\hline \multicolumn{4}{|c|}{ Average for the trail } \\
\hline $\mathrm{C}$ & 1 & $0.596^{* *}$ & $0.227^{* *}$ \\
\hline $\mathrm{N}$ & $0.596^{* *}$ & 1 & $-0.638^{* *}$ \\
\hline $\mathrm{C} / \mathrm{N}$ & $0.227^{* *}$ & $-0.638^{* *}$ & 1 \\
\hline
\end{tabular}

* Correlation is significant at the 0.05 level (2-tailed);

** Correlation is significant at the 0.01 level (2-tailed). aggregates. The value of the correlation coefficient was not significant in the 3-5 mm soil units only.

Averaged for the trial, distinct positive correlations between the values of $\mathrm{C}$ and $\mathrm{N}$ in soil and also between the content of $\mathrm{C}$ and the degree of organic matter enrichment with $\mathrm{N}$ were formed. The correlation of total $\mathrm{N}$ in soil with the $\mathrm{C} / \mathrm{N}$ ratio remained significant in a negative direction.

\section{Conclusions}

As a result of systematic implementation of different soil tillage systems, higher $\mathrm{N}$ and $\mathrm{C}$ concentrations were established by the layers according to constant plowing. Constant disking and its alternation with nil tillage increased the total $\mathrm{N}$ concentration with $15.6 \%$ and $11.1 \%$, respectively, in comparison with the constant plowing. The same was valid for $\mathrm{C}$ concentration in soil, but the highest increase was established in the variants with constant cutting and nil tillage. The exceeding was with $14.0 \%$ and $13.2 \%$, respectively, in comparison to constant plowing.

The redistribution of $\mathrm{N}$ and $\mathrm{C}$ depending on the structural soil units was most expressed in the $0-10 \mathrm{~cm}$ and 10-20 cm layers. The highest amounts of $\mathrm{C}$ and $\mathrm{N}$ were found in the soil units with size less than $5 \mathrm{~mm}$, 
mainly in the $<0.25 \mathrm{~mm}$ fraction. At depth $20-30 \mathrm{~cm}$, the role of the size of soil structural units for $\mathrm{C}$ and $\mathrm{N}$ redistribution decreased strongly. The minimal tillage and the tillage without turning of soil, used independently and in combination, had the highest contribution to preserving the organic matter in the haplic Chernozems of Dobrudzha.

The values of the $\mathrm{C} / \mathrm{N}$ ratio were moderate only under the use of constant disking. This index was low under all other soil tillage systems.

The correlation of total $\mathrm{N}$ with $\mathrm{C}$ in soil was high, positive and significant depending on the size of structural soil units and the tillage systems, in average for the investigated factors in this experiment.

\section{Acknowledgments}

The authors would like to show their special thanks to Mr. Sabanov, the president of Company “AGROGARD”, Silistra, for his financial support.

\section{References}

[1] Gentry, L. F., Ruffo, M. L., and Below, F. E. 2013. "Identifying Factors Controlling the Continuous Corn Yield Penalty.” Agron. J. 105 (2): 295-303.

[2] Conant, R. T., Easter, M., Paustian, K., Swan, A., and Williams, S. 2007. "Impacts of Periodic Tillage on Soil C Stocks: A Synthesis.” Soil Tillage Res. 95 (1-2): 1-10.

[3] Khan, S. A., Mulvaney, R. L., Ellsworth, T. R., and Boast, C. W. 2007. "The Myth of Nitrogen Fertilization for Soil Carbon Sequestration.” J. Environ. Qual. 36 (6): 1821-32.

[4] Al-Kaisi, M. M., Yin, X. H., and Licht, M. A. 2005. "Soil Carbon and Nitrogen Changes as Affected by Tillage System and Crop Biomass in a Corn-Soybean Rotation.” Applied Soil Ecol. 30 (3): 174-91.

[5] Licht, M. A., and Al-Kaisi, M. 2005. "Strip-Tillage Effect on Seedbed Soil Temperature and Other Soil Physical Properties.” Soil Tillage Res. 80: 233-49.

[6] DeFelice, M. S., Carter, P. R., and Mitchell, S. B. 2006. "Influence of Tillage on Corn and Soybean Yield in the United States and Canada.” Crop Manage 5 (1). doi:10.1094/CM-2006-0626-01-RS.

[7] Filcheva, E., and Tsadilas, C. 2002. "Influence of Cliniptilolite and Compost on Soil Properties.” Commun. of Soil Sci. and Plant Analysis 33 (3-4): 595-607.

[8] Filcheva, E. 2004. "Comparative Characteristic of Bulgarian Soils Related to Content, Composition and
Organic Carbon Pool.” Prof. Habilitation thesis, National Center for Agrarian Sciences, Institute of Soil Science "N. Poushkarov”, Sofia.

[9] Filcheva, E. 2007. "Characteristic of Bulgarian Soils in Content, Composition and Stocks of Organic Matter: Grouping of Bulgarian Sols.” In Sustainable Land Management. Sofia: Advertising and Publishing House Minerva, 191. (in Bulgarian)

[10] Poirier, V., Angers, D. A., Rochette, P., Chantigny, M. H., Ziadi, N., Tremblay, G., and Fortin, J. 2009. "Interactive Effects of Tillage and Mineral Fertilization on Soil C Profiles.” Soil Science Society of America Journal 73 (1): 255-61.

[11] Gregorich, E. G., Carter, M. R., Angers, D. A., and Drury, C. F. 2009. "Using a Sequential Density and Particle-Size Fractionation to Evaluate Carbon and Nitrogen Storage in the Profile of Tilled and No-till Soils in Eastern Canada.” Canadian Journal of Soil Science 89 (3): 255-67.

[12] Ubugunov, L., Ubugunova, V., and Merkusheva, M. 1990. "Humus and Nitrogen Content in Granulometric Fractions of Brown Soils of the West Baykal Region.” Soil Science 1: 80-6. (in Russian)

[13] Kiryushin, V. I., and Lebedeva, I. N. 1985. "Humus and Nitrogen in the Mechanical Fractions of the Khazakstan Chernozem Zone.” Agrochemistry 1: 70-6.

[14] FAO. 2006. World Reference Base for Soil Resources. Rome, Italy: FAO.

[15] Revut, I. 1972. Physics of Soils. Leningrad: Kolos Publisher, 368. (in Russian)

[16] Atanasov, I., Penkov, M., Stefanov, S., Dimitrov, G., and Totev, T. 1972. Handbook of Practical Exercises on Soil Science. Plovdiv: Chisto G. Danov Publisher, 51-4.

[17] Belchikova, N. P. 1975. "Determining Soil Humus by the Method of I.V. Tyurin.” In Agrochemical Methods for Soil Study. Moscow: Nauka Publisher, 56-62.

[18] Orlov, D. S., and Grishina, L. A. 1981. Practices in Humus Chemistry. Moskva: Moskovsky Universitet.

[19] Al-Kaisi, M. M., Elmore, R. W., Guzman, J. G., Hanna, H. M., Hart, C. E., Helmers, M. J., and Hodgson, E. W. 2013. "Drought Impact on Crop Production and Soil Environment: 2012 Experience from Iowa.” Soil Water Cons. J. 68 (1): 19-24.

[20] Wang, X. B., Cai, D. X., Hoogmoed, W. B., Oenema, O., and Perdok, U. D. 2006. "Potential Effect of Conservation Tillage on Sustainable Land Use: A Review of Global Long-Term Studies.” Pedosphere 16 (5): 587-95.

[21] Rasmussen, K. J. 1999. "Impact of Ploughless Soil Tillage on Yield and Soil Quality: A Scandinavian Review.” Soil Tillage Res. 53 (1): 3-14.

[22] Lal, R., and Kimble, J. M. 1997. "Conservation Tillage for Carbon Sequestration.” Nutr. Cycl. Agroecosyst. 49: 
243-53.

[23] Griffith, D. R., Kladivko, E. J., Mannering, J. V., West, T. D., and Parsons, S. D. 1988. "Long-Term Tillage and Rotation Effects on Corn Growth and Yield on High and Low Organic Matter, Poorly Drained Soils.” Agron. J. 80 (4): 599-605.

[24] Al-Kaisi, M. M., and Yin, X. H. 2004. "Stepwise Time Response of Corn Yield and Economic Return to No Tillage.” Soil Tillage Res. 78 (1): 91-101.

[25] Manley, J., Van Kooten, G. C., Moeltner, K., and Johnson, D. W. 2005. "Creating Carbon Offsets in Agriculture through No-till Cultivation: A Meta-Analysis of Costs and Carbon Benefits.” Climatic Change 68: 41-65.

[26] Shapiro, C. A., Holshouser, D. L., Kranz, W. L., Sheldon, P. D., Witkowski, J. F., Jarvi, K. J., Echtenkampa, G. W., Lunza, L. A., Frerichsa, R. D., Brentlingera, R. L., Lubberstedta, M. A., McCluskeyd, M. M., and Stroupe, W. W. 2001. "Tillage and Management Alternatives for
Returning Conservation Reserve Program Land to Crops.” Agron. J. 93 (4): 850-62.

[27] Wilhelm, W. W., and Wortmann, C. S. 2004. "Tillage and Rotation Interactions for Corn and Soybeans Grain Yield as Affected by Precipitation and Air Temperature.” Agron. J. 96: 425-32.

[28] Toliver, D. K., Larson, J. A., Roberts, R. K., English, B. C., DeLa Torre Ugarte, D. G., and West, T. O. 2012. "Effects of No-till on Yields as Influenced by Crops and Environmental Factors.” Agron. J. 104 (2): 530-41.

[29] Nankova, M., and Yankov, P. 2003. "Investigation on the Effect of Ploughing and Some Minimal Soil Tillage on the Soil Organic Matter Condition in the Haplic Chernozems.” Bulgarian Journal of Ecological Science "Ecology and Future" 2 (3-4): 101-2.

[30] Özpinar, S. 2009. "Tillage and Cover Crop Effects on Maize Yield and Soil Nitrogen.” Bulg. J. Agric. Sci. 15 (6): 533-43. 